\title{
AN UGARITIC TEXT RELATED TO THE FERTILITY CULT (KTU 1.23)
}

\section{Stanislav Segert}

At this conference on archaeology the opinion was expressed that it is possible to separate the objective description of archaeological finds from their interpretation, which may involve some subjective elements. Such a separation cannot be applied to written texts, whether found by archaeological excavation or transmitted by copying. This interdependence of description and interpretation is evident in ancient non-vocalized Semitic texts. A combination of three consonant letters can indicate either a noun or a verbal noun infinitive or participle - as well as a finite verbal form such as certain persons of the perfect or imperative. Only interpreting in context can indicate the category, the morphological characteristics and the syntactic function of such a word.

This applies to the ancient North Canaanite literary and liturgical texts excavated at Ras Shamra - ancient Ugarit - in Northern Syria on the shore of the Mediterranean. These cuneiform alphabetic tablets were written mostly in the 14 th century B.C., but traditions reaching several centuries back had been preserved on them.

The alphabetic cuneiform tablet containing a fertility ritual was found during the second excavation season directed by Claude Schaeffer in 1930, and published by Charles Virolleaud in 1933. Only about one half of the 76 lines of this tablet inscribed on both sides is completely preserved, but at the end probably no more than one line is missing (ample bibliographies in Caquot et al. 1974: 367-368 and Del Olmo Lete 1983: 427, n. 1).

The title used in modern literature, "Birth of Gracious Gods", is taken from the tablet (cf. lines 1-2, 23, 58). Its first part contains ritual instructions, the second part presents a mythological epic poem related to the ritual.

The first, liturgical part (lines 1-29) is divided by eight horizontal lines into nine sections, while the narrative continues in the second part (lines 30-76) without interruption. The parallelistic cola and verses of this epic poem only occasionally coincide with the graphic lines (previous research discussed by Xella 1973: 12-24; Caquot et al. 1974: 
357-358, 360-364; Del Olmo Lete 1983: notes to pp. 427-439; various translations in notes to pp. 440-448).

The first liturgical part begins with an invocation: / 'iqra'a 'ilima na "imima/ "I will invoke gracious gods" (line 1). A similar introductory formula opens the eighth liturgical section (line 23).

The liturgical character of the first part is indicated by objects and agents related to the cult - such as Prince Mot sitting with a scepter (lines 8-9) - as well as by instructions for ritual actions, such as eating bread and drinkıng wine (line 6), repeating of liturgical formulas (line 12), boiling of fat milk with herbs (line 19).

The agricultural function of this ritual is indicated by products and actions: / lahm-/ "bread", / hamr-/ and / yēn/ "wine" (line 6), care of vine (lines 9-11) and grapes (line 26), vineyard terraces (line 10), fields of gods and goddesses (lines 13 and 28).

The poetic narrative (lines 30-76) describes actions bringing fertility or related to it: The old supreme god Il overcame his impotence, the weakness of his member (lines 37-40), by shooting down a bird and roasting it on charcoal (lines 37-39). Then he was able to impregnate two wives of his. No names of wives are given in the narrative: they may be supplied from the introductory section (lines 13, 28) as atrt wrhm (y)/ 'atirat-) and / rahmay-/ (?). They gave birth to two gods, Šahar "Dawn" and Šalim "Dusk" (lines 42-53).

Afterwards, Il's wives gave birth to gracious gods (lines 58-61). Their names are not given, their number may be related to the instruction requiring to recite the story five times (line 57) as five or rather twice five: ten. These young gods devoured with wide open mouths birds of heaven and fish of the sea (lines 62-63). Then stones and woods of the holy desert are mentioned (lines 65-66). After seven years, poetically equal to eight cycles (lines 66-67), the gods came to the guardian of cultivated land (line 69) and asked for bread and wine (lines 71-72). The guardian provided what was requested (lines 73-74).

Two aspects of fertility, procreation and provision of food, appear in this Ugaritic text. Its use in the cult is indicated in the introductory sections. But the text itself does not give specific information for what festival in which agricultural season it had to be used. On the basis of some hints in the text various interpretations were put forward by modern scholars: festival at the beginning or at the end of grain harvest, festival connected with wine and grape gathering, ritual which 
had to provide abundant rain. Both spring and fall terms have been considered, the last one in connection with the New Year festival (cf. Caquot et al. 1974: 359; Del Olmo Lete (1983: 436-439).

Among analogies which could help to better understand this Ugaritic text, hydrophoria and hieros gamos were mentioned. These terms point to Greece, but both these rites were performed in East Mediterranean areas as well.

The connection of hydrophoria with the Ugaritic ritual text seems to be tenuous, since it is based on two fragmentary and problematic lines (30-31) where "sea shore" is mentioned. (Cf. Gaster 1966: 427-428; Caquot et al. 357. - A new interpretation of these lines: Del Olmo Lete 1984: 143-146). The comparison with better preserved similar lines 3536 does not support this interpretation.

According to some interpretations two women are lifting / mušta'alatēma/(?) water - which is not expressly indicated in the preserved text - to the top / lē-ra'ši/ of a vessel/'aggān-/. This interpretation of agn supported by Hebrew 'aggän (cf. Caquot et al. 1974: 357) is more appropriate than that proposed by Segert and Zgusta (1953: 274-275), "fire" with reference to Indo-European agni-(cf. Gordon 1965: 351; Xella 1973: 55). Insofar as hydrophoria at the Jerusalem temple - as described in post-biblical traditional literature(Mishnah, Sukkah4,910) - was supposed to assure abundant rain by imitating it, by pouring water down, it perhaps can be related to fertility cult. The other kind of hydrophoria, attested by Lucian (De Syria dea, 13, cf. 48) for Hierapolis in Northern Syria, was connected to the tradition of the flood, as was the rite performed in Athens (Nilsson 1955: 595-596).

The sacred marriage, hieros gamos, is well known from the ancient Near East (Jacobsen 1976: 32-47) as well as from ancient Greece (Nilsson 1955: 121-122). In some of these rites the king and queen acted. The use of sacred marriage in fertility rites is based on imitative magic: human fertility may assure fertility of animals and plants. Some relics of sacred marriage rites survived until recent times in agricultural rites performed in the Ukraine, Germany (Frazer 1964: 126-127), and Lithuania (Marija Gimbutas in the discussion of this paper).

The major part of the Ugaritic epic "Birth of Gracious Gods" (lines 33-61) describes in detail the intercourse of god Il with his two wives. No connection with a ritual action is indicated. The greetings / šalāmu/ to the King and the Queen in the introductory part (line 7) 
point to the participation of the royal couple in the ceremony, but do not give any direct hint to sacred marriage. If the narrative had to serve as model for a rite, two women and one man were expected to participate in it.

The sequence of various kinds of foods which were eaten by the young gracious gods was used as basis for an aetiological interpretation: The gods were first fed from the breast of the lady (line 61). Then they devoured birds and fish (lines 61-63). Only later, after seven or eight years, they moved from the desert to cultivated, sown land / madra'/ (lines 66-69), where they obtained from its guardian bread and wine (lines 69-76).

This sequence may reflect the progress of the human society, from living on meat of animals, birds and fish, to organized agriculture that could provide bread and wine (Caquot et al. 1974: 363-364).

The exact location and function of the Ugaritic liturgical text "Birth of Gracious Gods" remains in many aspects uncertain, even after respectable efforts of two generations of competent scholars. In fifty years since the editio princeps, consensus on a general understanding was reached. However, many details, especially in the first part, are still waiting for their exact interpretation. The fragmentary state of preservation and lack of close analogies may explain this situation.

Two features requiring further study may be mentioned: the meaning of the number of years, seven or eight, and the role of twins.

The words /šab" šanāt-/ "seven years" are followed by the parallel expression / tamāni n-qapat-/ "eight cycles" (lines 66-67). In this parallelistic poetic style the number functionally synonymous with sacred "7" is " $7+1$ ", i.e. " 8 " (cf. Segert 1983: 304). This parallel seems to weaken the relationship of the Ugaritic number " 7 " to other instances of the number "7", such as sabbatical years of ancient Israelites and 7+7 years in Joseph's story (Genesis, c. 41). In Ugaritic texts the number "7", especially if it is followed by the poetically functional synonym " 8 ", indicates a considerable interval of time between two actions, rather than an exact number.

This interval of 7 years appears several times in the epic cycles. In Baal epics it follows mention of fields (1. 12: II: 44-45), in Aqhat epics it gives the length of drought caused by the murder of young prince Aqhat (1. 19: I: 42-43). The length of seven or eight years in the poem; on gracious gods indicates their stay in the desert: the relationship of 
this interval to agricultural rites is not mentioned.

Among the details which may help a better understanding of this Ugaritic ritual text, the role of $t w o$ gods deserves attention. Sahar and Salim - "Dawn" and "Dusk" - were not twins, they were sons of different mothers. But they were fathered by the same god, conceived and born in the same time. They always appear together and can be considered functional twins.

To quote James Frazer (1964:71): "There is a widespread belief that twin children possess magical powers over nature, especially over rain and the weather". Some North American Indians used to spill water from baskets to produce rain. Mothers of twins - and even graves of twins - were considered instrumental for securing rain by Bantus in Southeastern Africa. The Heavenly Twins, Dioscuri, were credited by ancient Greeks with the power of allaying storms (Frazer Gaster 1964: 71-73, 177).

In the Ugaritic myth, god Il by impregnating two women at the same time produced two sons, who were functionally twins. The birth of twins, important as a symbol in a fertility cult, was more likely if two wives were impregnated, than if the birth of natural twins were left to chance.

The Ugaritic text "Birth of Gracious Gods" contains substantial data about the fertility cult. Further analysis of the text itself combined with sound use of structural analogies may extract more information from this relatively short and fragmentary document of the ancient Canaanite beliefs and practices. 


\section{Summary}

A contextual interpretation is applied to a tablet in alphabetic cuneiform from the 14th cent. B.C., found at Ras Shamra-Ugarit in Northern Syria, published in 1933. This ancient Canaanite text "Birth of Gracious Gods" contains a liturgical introduction and an epic poem: The god Il fathered sons from two wives. This fertility ritual was compared to other rites, such as hydrophoria - this connection is rather tenuous - and sacred marriage. It was also explained as a reflection of the progress of human society toward agriculture. Even after successful efforts in general interpretation, further studies of details are needed. The parallel expressions "seven years" - "eight cycles" indicate not an exact, but a considerable interval of time. Two gods "Dawn" and "Dusk" were sons of different mothers, but they were born from the same father at the same time; thus they may - as functional twins - be helpful in assuring abundant rains.

\section{Résumé}

Un texte ugaritique concernant le culte de fertilité (KTU 1.23).

Une interprétation en contexte est appliquée à une tablette en cunéiformes alphabétiques du 14ème siècle avant J.-C:, trouvée à Ras Shamra-Ugarit en Syrie du Nord, publiée en 1933. Cet ancien texte cananéen "La naissance des dieux gracieux" contient une introduction liturgique et un poème epique: Le dieu Il est devenu père des fils nés de deux épouses. Ce rituel de fertilité était comparé à d'autres rites, comme l'hydrophorie - ce rapport est très ténu - et le mariage sacré. Il était aussi expliqué comme réflexion du progrès de la société humaine vers l'agriculture. Même après des efforts réussis en interprétation générale, des études supplémentaires des détails sont nécessaires. Les expressions parallèles "sept années" - "huit cycles" dénotent un intervalle de temps, non exact, mais considérable. Les dieux "Aube" et "Crépuscule" etaient fils des mères différentes, mais ils étaient nés du même père au même temps; ainsi ils pouvaient - comme jumeaux fonctionaux - aider en assurant des pluies abondantes. 


\section{Bibliography}

Text editions (some with translations and commentaries):

DEL OLMO LETE, G.

1983 - Mitos y Leyendas de Canaan según la tradición de Ugarit, Madrid. [Text, Spanish tr., notes, introd.; pp. 427-448].

DIETRICH, M., LORETZ, O., SANMARTIN, J.

1976 - Die keilalphabetischen Texte aus Ugarit, 1, Kevelaer/ Neukirchen-Vluyn. [Abbr.: KTU.] [Nr. 1. 23].

GIBSON, J.C.L.

1978 - Canaanite Myths and Legends, Edinburgh. [Text, Engl. tr., notes; pp. 123-127, cf. pp. 28-30].

GORDON, C.H.

1965 - Ugaritic Textbook, Rome. [Nr. 52].

HERDNER, A.

1963 - Corpus des tablettes en cunéiformes alphabétiques découvertes à Ras Shamra-Ugarit de 1929 à 1939, Paris. [Nr. 23].

RIN, S.

1968 - Acts of the Gods [Hebr.] Jerusalem. [Text, Hebr. tr., notes].

VIROLLEAUD, Ch.

1933 - La naissance des dieux gracieux et beaux, Syria, XIV, pp. 128151. [Editio princeps, French tr., notes].

XELLA, P.

1973 - Il mito di $\breve{S} H R$ e $\breve{L} L M$ : Saggio sulla mitologia ugaritica, Roma. [Text, Ital. tr., commentary].

Translations:

CAQUOT, A., SZNYCER, M., HERDNER, A

1974 - Textes ougaritiques, I: Mythes et légendes, Paris. [Paris tr., notes, introd.; pp. 353-379].

GASTER, Th. H.

1950/1966 - Thespis: Ritual, Myth and Drama in the Ancient Near East, New York. [Engl. tr., notes; pp. 418-435; cf. pp. 406-417]. 
Other Literature:

DEL OLMO LETE, G.

1984 - Interpretación de la mitología cananea, Valencia.

FRAZER, J.G. (GASTER, Th. H., ed.)

1964 - The New Golden Bough, New York.

JACOBSEN, Th.

1976 - The Treasures of Darkness: A History of Mesopotamian Religion, New Haven.

MACLEOD, M.D., ed.

1980 - Luciani Opera, III, Oxford.

NILSSON, M.P.

1955 - Geschichte der griechischen Religion, I, München.

SEGERT, $\mathrm{S}$.

1983 - Parallelism in Ugaritic Poetry, Journal of the American Oriental Society, 103, pp. 295-306.

SEGERT, S. - ZGUSTA, L.

1953 - Indogermanisches in den alphabetischen Texten aus Ugarit, Archiv Orientálni, 21, pp. 272-275. 